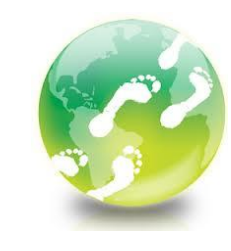

Jurnal Teknologi Kimia Unimal

homepage jurnal: https://ojs.unimal.ac.id/jtk
Jurnal

Teknologi

Kimia

Unimal

\title{
PEMURNIAN MINYAK JELANTAH MENGGUNAKAN KARBON AKTIF DARI BIJI SALAK (Salacca Zalacca) SEBAGAI ADSORBEN ALAMI DENGAN AKTIVATOR $\mathrm{H}_{2} \mathrm{SO}_{4}$
}

\author{
Dinda Robiatul Al Qory, Zainuddin Ginting*, Syamsul Bahri \\ Jurusan Teknik Kimia, Fakultas Teknik, Universitas Malikussaleh \\ Kampus Utama Cot Teungku Nie Reuleut, Muara Batu, Aceh Utara - 24355 \\ Korespondensi: 0811676666, zginting@unimal.ac.id
}

\begin{abstract}
Abstrak
Produksi minyak jelantah di Indonesia dewasa ini telah mencapai 4 juta ton/tahun. Oleh karena itu, diperlukan pemurnian untuk dapat digunakan kembali. Penelitian ini melaporkan proses pembuatan karbon aktif dari dari biji salak dan aplikasinya pada pemurnian minyak jerantah. Biji salak mengadung selulosa dan senyawa aktif lainnya sehingga dapat dijadikan sebagai karbon aktif dalam pemurnian minyak jelantah. Penelitian ini bertujuan untuk mempelajari proses pembuatan karbon aktif dari biji salak dan pengaruh massa karbon aktif, ukuran adsorben, dan waktu adsorpsi pada proses pemurnian minyak. Biji salak kering dipanaskan pada suhu $350{ }^{\circ} \mathrm{C}$ selama 1,5 jam dalam furnace. Karbon dihaluskan dan diayak menjadi 80 dan 100 mesh untuk diaktivasi menggunakan $\mathrm{H}_{2} \mathrm{SO}_{4}$. Penjernihan minyak dilakukan dengan mencampurkan minyak panas dengan karbon aktif sesuai variabel yang ditetapkan, yaitu: massa, waktu adsorpsi, dan ukuran adsorben. Minyak hasil adsorpsi memiliki kadar FFA 0,108\%, bilangan asam 0,244 mg KOH/g, kadar air 0,062\%, dan bilangan peroksida sebesar 2,5 mek $\mathrm{O}_{2} / \mathrm{kg}$, Hasil ini diperoleh pada penggunaan massa karbon aktif 30 gram, ukuran adsorben 100 mesh, waktu adsorpsi 90 menit dan waktu adsorpsi 120 menit.
\end{abstract}

Kata kunci: Biji Salak, Furnace, Karbon Aktif, Minyak Jelantah, Waktu Adsorpsi

\section{Pendahuluan}

Minyak goreng merupakan salah satu kebutuhan pokok manusia sebagai alat pengolah bahan - bahan makanan khususnya dalam hal menggoreng. Minyak goreng digunakan secara luas di seluruh belahan dunia termasuk di Indonesia. Minyak goreng yang digunakan secara berkali-kali atau lebih dikenal dengan minyak jelantah merupakan minyak yang tidak layak dipakai lagi dan akan berdampak pada kesehatan apabila tetap dikonsumsi dikarenakan didalamnya 
mengandung senyawa-senyawa karsinogenik, seperti peroksida dan asam lemak bebas yang tinggi.

Jumlah produksi minyak jelantah di Indonesia yang telah mencapai 4 juta ton/tahun (Rahkadima dan Purwati, 2011) memerlukan penanganan yang baik agar tidak terjadi pencemaran lingkungan. Pembuangan minyak jelantah secara langsung (tanpa pengolahan) selain dapat mengganggu tubuh, air juga dapat merusak struktur tanah karena menghambat pergerakan air pada pori-pori tanah. Beberapa upaya yang dapat dilakukan untuk mengurangi dampak buruk minyak jelantah adalah mengubah minyak jelantah menjadi bahan baku pembuatan biodiesel dan sabun.

Minyak jelantah tidak dapat langsung digunakan sebagai bahan baku biodiesel maupun sabun, karena mengandung senyawa-senyawa karsinogenik. Maka dari itu, perlu dilakukan pemurnian terhadap minyak jelantah. Metode yang dapat digunakan untuk pemurnian minyak jelantah salah satunya adalah adsorpsi. Adsorpsi dianggap sebagai metode yang ekonomis dan efektif karena biaya yang relatif murah, dapat diregenerasi serta relatif sederhana. Adsorpsi merupakan suatu proses penyerapan oleh padatan tertentu terhadap zat tertentu. Adsorben didefenisikan sebagai zat padat yang dapat menyerap komponen tertentu dari suatu fluida (Arfan, 2006).

Hampir semua daerah di Indonesia dapat ditumbuhi salak, baik yang telah dibudidayakan maupun yang masih tumbuh liar. Saat ini banyak industri pengolahan salak yang menghasilkan limbah biji salak. Bagian buah salak yang bisa dimakan sekitar 56-65\%, sedangkan limbahnya 35-44\%, sehingga limbah salak dapat mencapai $35-44 \%$ dari jumlah salak yang diolah atau dikonsumsi. Biji salak merupakan limbah dari buah salak yang memiliki porsi yang lebih besar daripada kulit salak. Biji salak porsinya sebesar 25-30\% dari buah salak utuh, sedangkan kulit salak 10-14\%. Berdasarkan perbandingan tersebut, biji salak memiliki potensi yang lebih besar untuk dimanfaatkan.

Menurut penelitian (Nugroho, 2014) biji salak memiliki kandungan kimia berupa karbohidrat yang terhitung dari tepungnya sejumlah $88,35 \%$, yang terdiri dari $28,98 \%$ selulosa dan $59,37 \%$ karbohidrat lain yang teridentifikasi sebagai 
hemiselulosa berupa mannan, atau setara dengan 36,28\% karbohidrat dari biji salak segar yang terdiri dari $11,90 \%$ selulosa dan $24,38 \%$ mannan. Selulosa dan senyawa aktif yang terkandung pada biji salak ini sehingga dapat dijadikan sebagai bioadsorben.

Karbon aktif merupakan padatan berpori yang dibuat dari bahan baku yang mengandung karbon. Apabila karbon aktif dipanaskan pada suhu $250-400^{\circ} \mathrm{C}$ fungsinya adalah untuk menghilangkan kandungan air yang ada didalam arang aktif tersebut, dan dapat kita gunakan sebagai penyerap gas atau cairan. Sehingga karbon aktif diharapkan mampu menyerap asam lemak bebas, pengotor maupun koloid yang ada dalam minyak goreng bekas. Untuk meningkatkan kemampuan penyerapan karbon aktif maka perlu dilakukan aktivasi.

Penelitian pemurnian minyak jelantah telah dilakukan oleh (Rahayu et al., 2014), menggunakan sabut dan tempurung kelapa sebagai adsorben dengan parameter pengujiannya yaitu, uji bilangan peroksida dan asam lemak bebas. Dari penelitian tersebut diperoleh data bahwa adsorben sabut kelapa lebih efektif memberi penurunan kadar asam lemak bebas dan peroksida dibandingkan adsorben tempurung kelapa dengan persentase penurunannya sebesar $75,73 \%$ terhadap kadar asam lemak bebas dan penurunan sebesar 93,39\% terhadap kadar peroksida pada minyak jelantah. Berdasarkan uraian diatas, maka penulis melakukan penelitian mengenai Pemurnian Minyak Jelantah Menggunakan Karbon Aktif dari Biji Salak (Salacca Zalacca) dengan Aktivator $\mathrm{H}_{2} \mathrm{SO}_{4}$.

\section{Bahan dan Metode}

Bahan dan peralatan yang diperlukan dalam penelitian ini antara lain adalah biji salak, minyak jelantah penggorengan ayam, $\mathrm{H}_{2} \mathrm{SO}_{4} 0,1 \mathrm{~N}$, indikator phenolptalein, $\mathrm{NaOH} 0,1 \mathrm{~N}$, aquades, kloroform, kalium iodida, amilum, asam asetat, $\mathrm{Na}_{2} \mathrm{~S}_{2} \mathrm{O}_{3}$, oven, erlenmeyer, beaker glass, hot plate, neraca analitik, termometer, pipet tetes, corong, magnetic stirrer, ayakan 80 dan 100 mesh, mortar, dan furnace. Pemurnian minyak jelantah diawali dengan melakukan analisa awal, kemudian minyak jelantah dipanaskan pada suhu $90^{\circ} \mathrm{C}$ dan karbon aktif dimasukkan kedalam minyak jelantah sesuai massa, ukuran adsorben, dan 
waktu adsorpsi yang ditentukan. Kemudian dilakukan uji kadar FFA, bilangan asam, kadar air dan bilangan peroksida.

Penelitian ini terdiri dari dua tahap yaitu pembuatan karbon aktif (termasuk aktivasi) dan pemurnian minyak jelantah. Variasi percobaan dilakukan terhadap massa karbon aktif yaitu 10;15;20;30 gram, ukuran adsorben 80 dan 100 mesh dan waktu adsorpsi 30;60;90;120 menit. Pembuatan karbon aktif dilakukan dengan pembelahan biji salak menjadi bagian lebih kecil dan dibakar di dalam furnace pada suhu $350^{\circ} \mathrm{C}$ selama 1,5 jam, karbon dihaluskan dan diayak menggunakan ayakan berukuran 80 dan 100 mesh, kemudian diaktivasi secara kimia dengan $\mathrm{H}_{2} \mathrm{SO}_{4} 0,1 \mathrm{~N}$ dan dibilas dengan aquades sampai $\mathrm{pH}$ netral.

\section{Hasil dan Diskusi}

\subsection{Pengaruh Massa Karbon Aktif, Ukuran Adsorben dan Waktu Adsorpsi Terhadap Kadar FFA}

Asam lemak bebas atau free fatty acid (FFA) adalah asam lemak yang berada sebagai asam bebas tidak terikat sebagai trigliserida. Semakin tinggi frekuensi pemakaian minyak goreng maka kadar asam lemak bebas semakin meningkat. Semakin tinggi asam lemak bebas pada minyak nabati maka kualitas minyak tersebut semakin rendah. Menurut Standar Nasional Indonesia (SNI, 2013) kadar FFA pada minyak goreng yaitu 0,3\%. Pengaruh massa karbon aktif, ukuran adsorben, dan waktu adsorpsi terhadap kadar FFA dapat dilihat pada Gambar 1

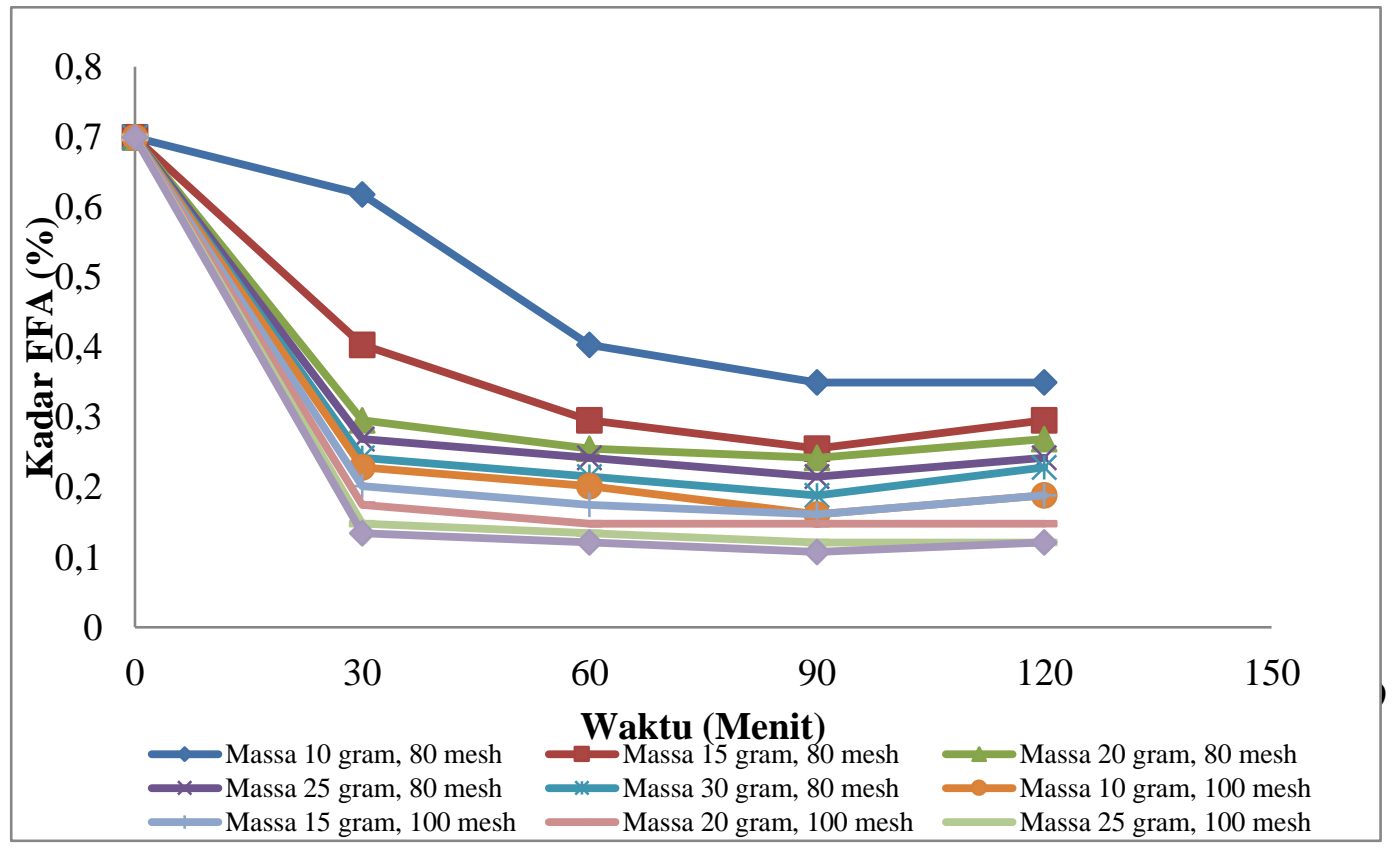


Gambar 1. Grafik Pengaruh Massa Karbon Aktif, Ukuran Adsorben, dan Waktu Adsorpsi Terhadap Kadar FFA

Berdasarkan Gambar 1 menunjukkan bahwa massa karbon aktif, ukuran adsorben, dan waktu adsorpsi mempengaruhi kadar FFA pada minyak jelantah yaitu semakin besar massa karbon aktif maka kadar FFA pada minyak jelantah setelah adsorpsi semakin kecil. Hal ini dikarenakan dengan bertambahnya jumlah massa adsorben maka semakin banyak pusat aktif adsorben yang bereaksi dengan kandungan FFA didalam minyak jelantah sehingga menghasilkan interaksi yang cukup efektif.

Semakin kecil ukuran adsorben maka kadar FFA pada minyak jelantah setelah adsorpsi semakin kecil. Hal ini dikarenakan semakin kecil ukuran adsorben yang digunakan menyebabkan luas permukaan semakin besar sehingga terjadinya interaksi yang sangat efektif antara sisi aktif pada adsorben dengan adsorbat. Hal ini juga sesuai dengan penelitian (Robiah et al., 2018) yang menyatakan bahwa efisiensi adsorpsi merupakan fungsi luas permukaan adsorben. Semakin besar luas permukaan adsorben semakin besar pula kapasitas suatu adsorben dalam mengadsorpsi suatu adsorbat.

Semakin lama waktu adsorpsi maka kadar FFA pada minyak jelantah setelah adsorpsi semakin kecil sampai pada waktu tertentu akan mencapai maksimum dan setelah itu akan naik kembali, hal ini dinamakan waktu optimum. Pada penelitian ini, waktu kontak optimum diperoleh pada waktu 90 menit. Kadar FFA mulai kembali naik pada waktu 120 menit. Hal ini menunjukkan bahwa adanya batas adsorben dalam mengadsorpsi FFA yang terkandung dalam minyak jelantah karena jenuhnya sisi aktif adsorben. Kadar FFA minyak jelantah sebelum diadsorpsi sebesar 0,699\% dan setelah diadsorpsi kadar FFA menurun hingga $0,108 \%$.

\subsection{Pengaruh Massa Karbon Aktif, Ukuran Adsorben dan Waktu Adsorpsi Terhadap Bilangan Asam}

Angka asam adalah jumlah miligram $\mathrm{KOH}$ yang diperlukan untuk menetralkan asam lemak bebas yang terdapat dalam satu gram minyak atau 
lemak. Bilangan asam dalam minyak sering digunakan sebagai salah satu parameter kerusakan minyak goreng bekas pakai. Menurut Standar Nasional Indonesia (SNI, 2013) bilangan asam pada minyak goreng yaitu $0,6 \mathrm{mgKOH} / \mathrm{g}$. Pengaruh massa karbon aktif, ukuran adsorben, dan waktu adsorpsi terhadap bilangan asam dapat dilihat pada Gambar 2

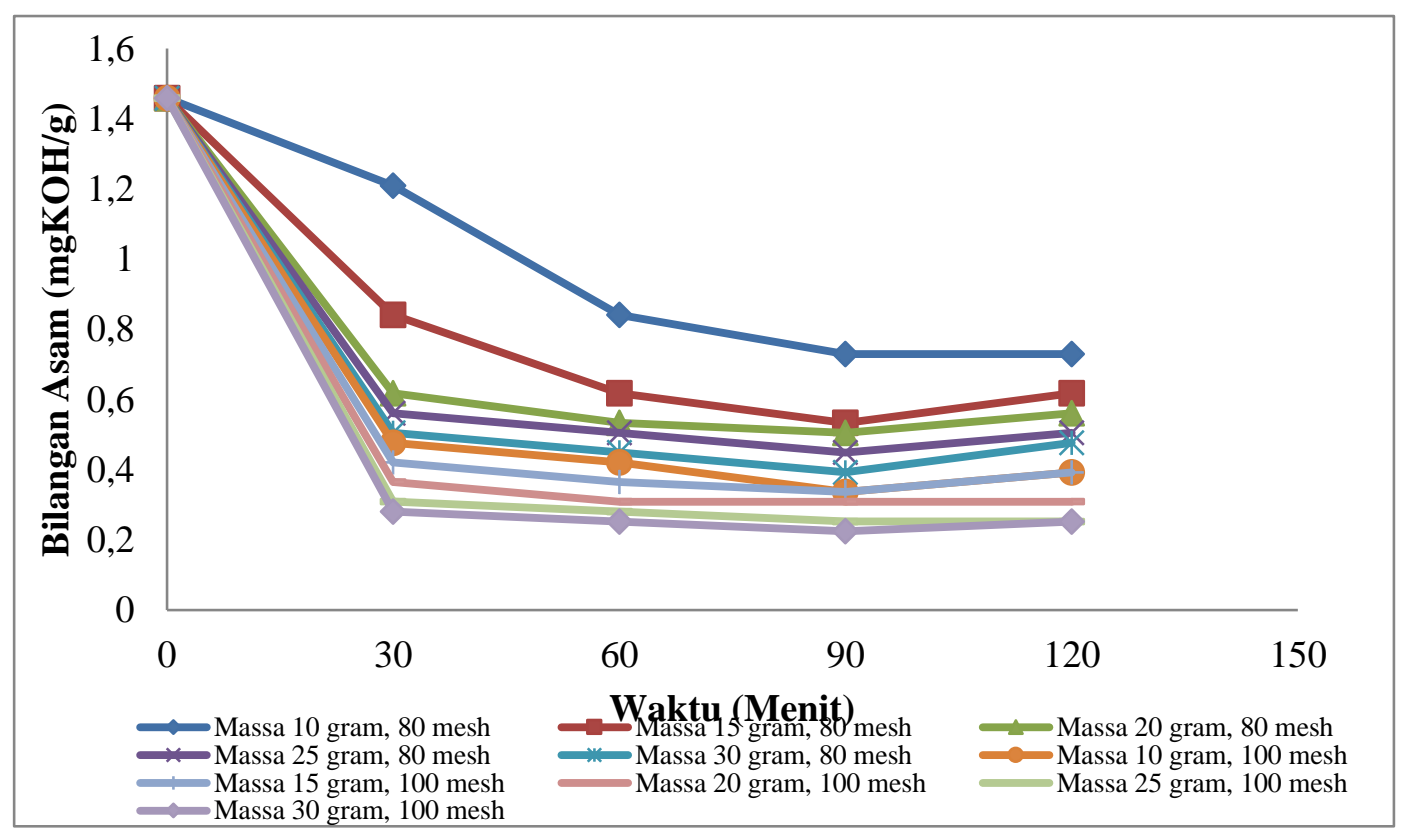

Gambar 2. Grafik Pengaruh Massa Karbon Aktif, Ukuran Adsorben,dan Waktu Adsorpsi Terhadap Bilangan Asam

Berdasarkan Gambar 2 menunjukkan bahwa massa karbon aktif, ukuran adsorben, dan waktu adsorpsi mempengaruhi bilangan asam pada minyak jelantah yaitu semakin besar massa karbon aktif maka bilangan asam pada minyak jelantah setelah adsorpsi semakin kecil. Hal ini dikarenakan dengan bertambahnya jumlah massa adsorben maka semakin banyak tumbukan antara adsorbat dengan permukaan aktif adsorben sehinggan bilangan asam yang diserap semakin meningkat.

Semakin kecil ukuran adsorben maka bilangan asam pada minyak jelantah setelah adsorpsi semakin kecil. Hal ini dikarenakan semakin kecil ukuran adsorben yang digunakan menyebabkan luas permukaan semakin besar sehingga bilangan asam yang diserap semakin banyak. Hal ini didukung oleh penelitian (Kartika Udyani et al., 2018) yang menyatakan bahwa peristiwa tumbukan antara 
partikel dengan permukaan aktif adsorben akan meningkat dengan meningkatnya luas permukaan aktif adsorben.

Pada waktu 30 sampai 90 menit bilangan asam terus mengalami penurunan, tetapi setelah waktu 120 menit bilangan asam mulai naik kembali, hal ini menunjukkan bahwa waktu kontak optimum yaitu pada waktu 90 menit. Hal ini menunjukkan bahwa adanya batas adsorben dalam mengadsorpsi bilangan asam yang terkandung dalam minyak jelantah. Bilangan asam minyak jelantah sebelum diadsorpsi sebesar 1,459 $\mathrm{mg} \mathrm{KOH} / \mathrm{g}$ dan setelah diadsorpsi bilangan asam turun hingga $0,224 \mathrm{mgKOH} / \mathrm{g}$.

\subsection{Pengaruh Massa Karbon Aktif, Ukuran Adsorben dan Waktu Adsorpsi Terhadap Kadar Air}

Kadar air menjadi peran penting dalam ketengikan minyak dan merupakan salah satu bentuk kerusakan yang disebabkan oleh aksi oksigen terhadap lemak bebas dalam produk (Bahri, 2014). Menurut Standar Nasional Indonesia (SNI, 2013) kadar air pada minyak goreng yaitu 0,15\%. Pengaruh massa karbon aktif, ukuran adsorben, dan waktu adsorpsi terhadap kadar air dapat dilihat pada Gambar 3

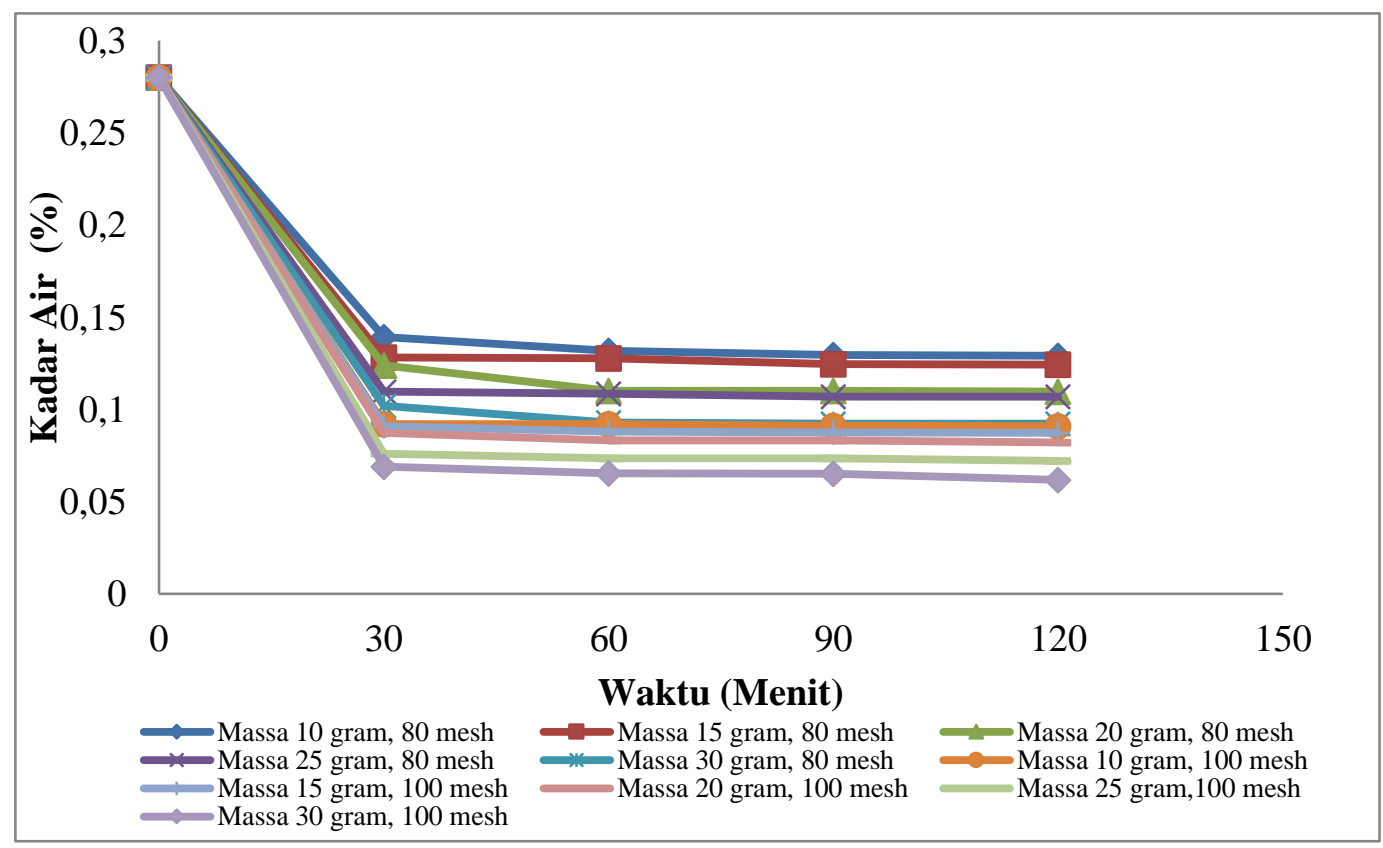

Gambar 3. Grafik Pengaruh Massa Karbon Aktif, Ukuran Adsorben, dan Waktu Adsorpsi Terhadap Kadar Air 
Berdasarkan Gambar 3 menunjukkan bahwa massa karbon aktif, ukuran addsorben, dan waktu adsorpsi mempengaruhi kadar air pada minyak jelantah yaitu semakin besar massa karbon aktif maka kadar air minyak jelantah setelah adsorpsi semakin kecil. Hal ini juga sesuai pernyataan (Rosita dan Arum Widasari, 2009) dalam penelitiannya menyatakan bahwa karbon aktif akan menyerap air dalam minyak dan seiring penambahan jumlah karbon aktif, maka semakin banyak air yang diserap.

Semakin kecil ukuran adsorben maka kadar air pada minyak jelantah setelah adsorpsi semakin kecil. Hal ini dikarenakan ukuran adsorben yang kecil akan memperbesar luas permukaan sehingga daya adsorpsinya semakin baik. Semakin lama waktu adsorpsi maka kadar air pada minyak jelantah setelah adsorpsi semakin kecil. Hal ini dikarenakan dengan lamanya waktu adsorpsi akan semakin banyak waktu (kesempatan) penyerapan yang terjadi. Kadar air pada minyak jelantah sebelum diadsorpsi sebesar 0,28\% dan setelah diadsorpsi kadar air turun hingga $0,062 \%$.

\subsection{Pengaruh Massa Karbon Aktif, Ukuran Adsorben dan Waktu Adsorpsi Terhadap Bilangan Peroksida}

Angka peroksida merupakan salah satu nilai untuk menentukan derajat kerusakan pada minyak. Ikatan rangkap pada asam lemak tidak jenuh dapat mengikat oksigen sehingga membentuk peroksida yang tidak stabil. Peroksida dapat mengalami reaksi lebih lanjut membentuk aldehid (Yustinah et al., 2017). Menurut Standar Nasional Indonesia (SNI, 2013) bilangan peroksida pada minyak goreng yaitu $10 \mathrm{mekO}_{2} / \mathrm{kg}$. Adapun grafik pengaruh massa karbon aktif, ukuran adsorben, dan waktu adsorpsi terhadap bilangan peroksida dapat dilihat pada Gambar 4.4 


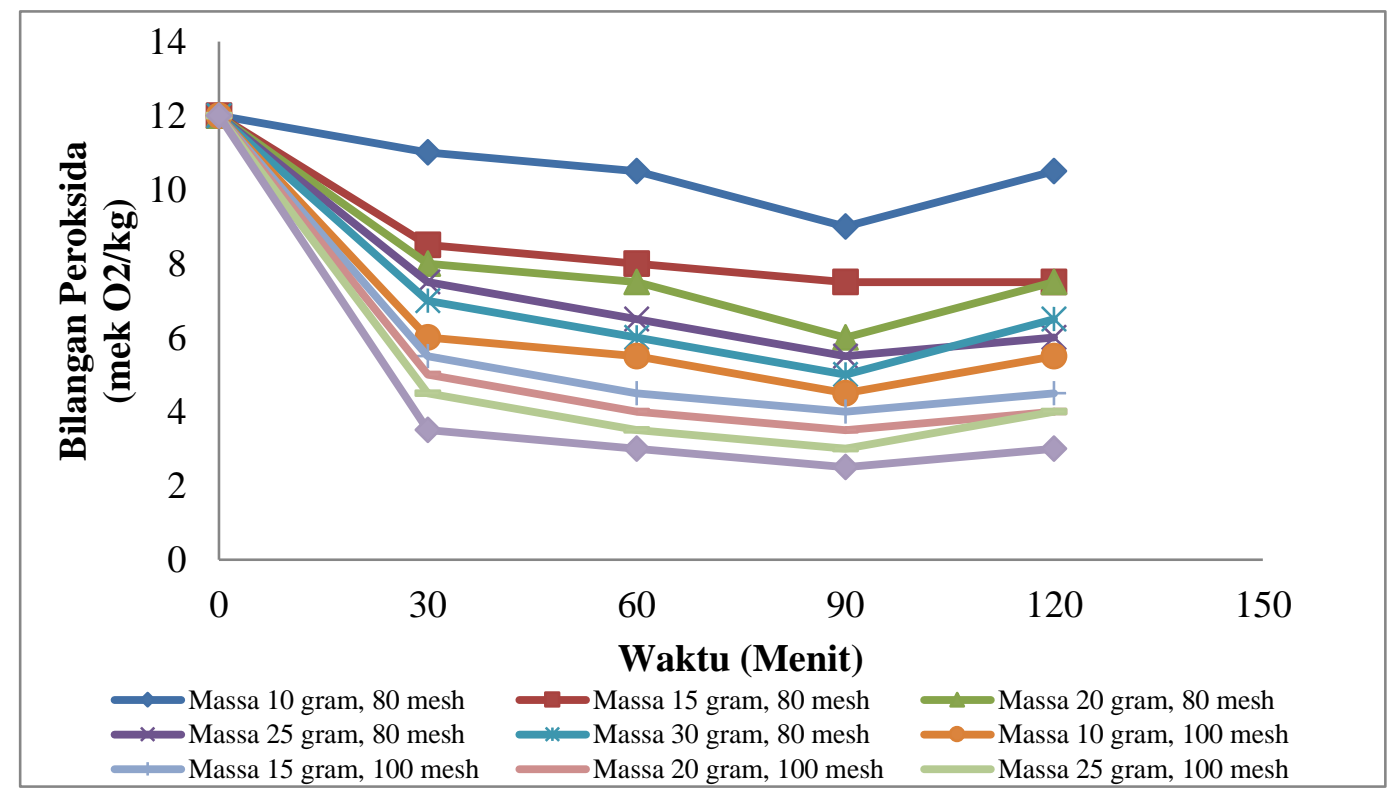

Gambar 4. Grafik Pengaruh Massa Karbon Aktif, Ukuran Adsorben, dan Waktu Adsorpsi Terhadap Bilangan Peroksida

Berdasarkan Gambar 4 menunjukkan bahwa massa karbon aktif, ukuran adsorben, dan waktu adsorpsi mempengaruhi bilangan peroksida pada minyak jelantah yaitu semakin besar massa karbon aktif maka bilangan peroksida pada minyak jelantah setelah adsorpsi semakin kecil. Hal ini juga sesuai penelitian (Meriatna et al., 2020) yang menyatakan bahwa dengan bertambahnya jumlah massa adsorben maka semakin banyak yang berinteraksi dan tingkat penyerapan semakin tinggi. Penyerapan bilangan peroksida pada minyak jelantah ukuran 100 mesh lebih baik daripada ukuran 80 mesh. Hal ini dikarenakan makin besar ukuran mesh maka jumlah partikel semakin besar dan memiliki luas permukaan yang besar sehingga kemampuan daya serap juga makin besar.

Pada waktu 30 sampai 90 menit bilangan peroksida terus mengalami penurunan, tetapi setelah waktu 120 menit bilangan peroksida naik kembali, hal ini menunjukkan bahwa waktu kontak optimum yaitu pada waktu 90 menit. Waktu optimum reaksi merupakan waktu efektif dan efisien terhadap penurunan bilangan peroksida pada minyak jelantah. Hal ini dikarenakan adsorben sudah jenuh pada waktu tersebut sehingga penyerapan menjadi tidak maksimal. Bilangan peroksida pada minyak jelantah sebelum diadsorpsi sebesar 12 mek $\mathrm{O}_{2} / \mathrm{kg}$ dan setelah diadsorpsi bilangan peroksida turun hingga 2,5 mek $\mathrm{O}_{2} / \mathrm{kg}$. 


\section{Simpulan dan Saran}

Pemurnian minyak jelantah dipengaruhi massa karbon aktif, ukuran adsorben, dan waktu adsorpsi. Semakin besar massa karbon aktif, ukuran mesh, dan waktu adsorpsi maka penyerapan kadar FFA, bilangan asam, kadar air dan bilangan peroksida semakin meningkat. Kondisi terbaik penurunan kadar FFA, bilangan asam, kadar air, dan bilangan peroksida minyak jelantah yaitu pada massa karbon aktif 30 gram, ukuran adsorben 100 mesh dan waktu adsorpsi 90 menit dan kadar air pada waktu adsorpsi 120 menit dengan nilai 0,108\%; 0,244 mg KOH/g; 0,062\%; dan 2,5 mek $\mathrm{O}_{2} / \mathrm{kg}$

Penelitian ini dapat dilanjutkan dengan dengan melakukan pemurnian minyak jelantah menggunakan karbon aktif secara aktivasi fisika agar dapat dibandingkan hasil pemurniannya.

\section{Daftar Pustaka}

1. Bahri, S. (2014). Pengaruh Adsorben Bentonit Terhadap Kualitas Pemucatan Minyak Inti Sawit. J. Dinamika Penelitian Industri, 25(1), 6370.

2. Kartika Udyani, Dwi Sari, M. (2018). Uji Kemampuan Adsorpsi Zeolit Alam Teraktivasi Asam Sulfat pada Penurunan Bilangan Asam Biodiesel. Prosiding Seminar Nasional Teknik Kimia "Kejuangan," http://jurnal.upnyk.ac.id/index.php/kejuangan/article/view/2285

3. Meriatna, Novi Sylvia, Suryati, Fajar Sidiq Siregar, Leni Maulinda, Z. (2020). Optimasi Kondisi Proses Adsorbsi Untuk Meningkatkan Kualitas Cpo Menggunakan Adsorben Karbon Aktif Sisa Pembakaran Cangkang Kelapa Sawit Pada Batch Column. Jurnal Teknologi Kimia Unimal, 1(9:), $46-57$.

4. Nugroho. (2014). Studi Potensi Biji Salak (Salacca edulis Reinw) Sebagai Sumber Alternatif Monosakarida dengan Cara Hidrolisis Menggunakan Asam Sulfat. Prosiding SEMNASTEK Fakultas Teknik Universitas Gadjah Mada, November, 1-4.

5. Rahayu, L., Purnavita, S., \& Sriyana, H. (2014). Potensi Sabut Dan 
Tempurung Kelapa Sebagai Adsorben Untuk Meregenerasi Minyak Jelantah. Jurnal Momentum UNWAHAS, 10(1), 47-53.

6. Rahkadima, Y., dan Purwati, P. A. (2011). Pembuatan Biodiesel dari Minyak Jelantah Melalui Proses Transesterifikasi Dengan Menggunakan CaO Sebagai Katalis. Jurnal Teknik Kimia, 19(3), 44-53.

7. Robiah, Netty Herawaty, W. C. (2018). Regenerasi Minyak Goreng Bekas Sebagai Bahan Baku Biodiesel Menggunakan Ampas Tebu Sebagai Adsorben. Jurnal Distilasi, 3(Vol 3, No 1: Jurnal Distilasi), 41-46. http://jurnal.um-palembang.ac.id/distilasi/article/view/1882

8. Rosita, A. fradiani, \& ArumWidasari, W. (2009). Peningkatan Kualitas Minyak Goreng Bekas Dari Kfc Dengan Menggunakan Adsorben Karbon Aktif. Seminar Tugas Akhir S1 Jurusan Teknik Kimia UNDIP

9. SNI. (2013). Minyak Goreng-SNI 3741:2013. www.bsn.go.id

10. Yustinah;, Utomo, S., \& Cardosh, S. R. (2017). Pengaruh Waktu Adsorbsi Dalam Proses Pemurnian Minyak Goreng Bekas Menggunakan Bioadsorben Tandan Kosong Kelapa Sawit. Seminar Nasional Sains Dan Teknologi UMJ 2017, November, 1-2. 